\title{
PENGARUH PELAYANAN DAN KEPUASAN TERHADAP LOYALITAS NASABAH KREDIT PADA PT. BPR X
}

\section{EFFECT OF SERVICE AND CUSTOMER SATISFACTION TO CREDIT CUSTOMERS IN PT. BPR X}

\author{
Faisal H. Batubara, SE, MSi \\ Politeknik APP Jakarta, Kementerian Perindustrian \\ feibatoebara@gmail.com
}

\begin{abstract}
The purpose of this study is to determine how much influence between the services provided and the level of satisfaction obtained on loyalty of credit customers at PT. BPR X. Techniaues used in collecting data is using the method of field observation, interviews to respondents and the distribution of questionnaires. The population used in this research is credit customers of PT BPR $X$ which amounted to 386 credit customers, sampling technique used is a purposive method obtained by the sample of 60 respondents or by $15 \%$ of the population. Methods of daia analysis using multiple linear regression analysis, correlation test, determinant test, partial $t$ test and multiple $F$ test. The result of multiple linear regression analysis shows that $Y=0,254+0,474 X 1$ $+0,445$ X2 meaning without Xeria veriabel (service) and X2 (satisfaction) then variable $Y$ (satisfaction) remain 0,254. Based on the correlation test results of correlation value of 0,533 which means having a medium relationship in accordance with the criterion limits that have been determined at the correlation interval (0.40 - 0.59 category strong enough). The determinant test shows the value of $R$ square of 0.284, which means the influence of service variables and satisfaction on the loyalty variable is $28.4 \%$, the rest of $71.6 \%$ is influenced by other independent variables which are not included in this research that is the level of competition, market demand , price, promotion, and so on. The result of t test is obtained by $t$ value of service variable $(2,169)>$ $t$-table (1,671) with significance value 0,034 below 0,05 hence it shows that service variable does not have significant influence to loyalty and obtained value t-count variable customer satisfaction (3.653)> t-table (1,671) with a significance value of 0.001 below 0.05 then it shows that customer satisfaction variables does not significantly influence loyalty. The result of $F$ test shows that service (X1) and customer satisfaction (X2) have positive effect and significant on Customer loyalty $(Y)$, this is proven by $F$ test calculation obtained $F$ count $=11,313$ bigger than Ftable 2,370. The significant level obtained is $(0,000)$ this value can be said to be absolutely significant because it is valued at 9,000 and smaller than the significant standard (5\% or 0.05)

Keywords : Service, Satisfaction, Loyalty, Customer
\end{abstract}

\section{ABSTRAK}

Penulisan ini bertujuan untuk mengetahui seberapa besar pengaruh antara pelayanan yang diberikan dan tingkat kepuasan yang didapatkan terhadap loyalitas nasabah kredit pada PT. BPR $\mathrm{X}$. Teknik yang digunakan dalam mengumpulkan data dengan menggunkan metode observasi 
lapangan, wawancara dan penyebaran kuisioner. Populasi adalah nasabah kredit PT. BPR X yang berjumlah 386 nasabah kredit, teknik sampling yang digunakan adalah metode purposive diperoleh sampel sebesar 60 responden atau sebesar $15 \%$ dari populasi. Metode analisis data menggunakan analisis regresi linier berganda, uji korelasi, uji determinan, uji t parsial dan uji $\mathrm{F}$ berganda. Hasil analisis regresi linier berganda menunjukkan persamaan yaitu $\mathrm{Y}=0,254+0,474 \mathrm{X} 1+0,445 \mathrm{X} 2$ yang berarti tanpa adanya veriabel X1 (pelayanan) dan X2 (kepuasan) maka variable Y (kepuasan) tetap sebesar 0,254. Berdasarkan hasil uji korelasi nilai korelasi sebesar 0,533 yang berarti memiliki hubungan sedang sesuai dengan batas kriteria yang telah ditentukan pada interval korelasi $(0,40-0,59=$ kategori cukup kuat). Uji determinan menunjukkan nilai R square sebesar 0,284 yang berarti besarnya pengaruh variable pelayanan dan kepuasan terhadap variable loyalitas adalah $28,4 \%$, sisanya sebesar $71,6 \%$ dipengaruhi variabel bebas lainnya yang tidak termasuk dalam penelitian ini yaitu tingkat persaingan, permintaan pasar, harga, promosi, dan sebagainya. Hasil uji t parsial diperoleh nilai t-hitung variabel pelayanan $(2,169)>\mathrm{t}$-tabel $(1,671)$ dengan nilai signifikansi sebesar 0,034 dibawah 0,05 maka hal tersebut nnenunjukan bahwa variabel pelayanan tidak berpengaruh signifikan terhadap loyalitas dan diperoleh nilai t-hitung variabel kepuasan nasabah $(3,653)>\mathrm{t}$-tabel $(1,671)$ dengan nilai signifikansi sebesar 0,001 di bawah 0,05 maka hal tersebut menunjukan bahwa variabel kepuasan nasabah tidak berpengaruh signifikan terhadap loyalitas. Hasil uji F menunjukkan bahwa pelayanan (X1) dan kepuasan nasabah (X2) berpengaruh positif dan sognifikan terhadap loyalitas Nasabah (Y), hal ini terbukti dengan perhitungan uji $\mathrm{F}$ diperoleh $\mathrm{F}$ hitung $=11,313$ lebih besar dari $\mathrm{F}$ tabel 2,370. Tingkat signifikan yang diperoleh adalah $(0,000)$ nilai ini dapat dikatakan mutlak signifikan karena bernilai 0,000 dan lebih kecil dari standar signifikan $(5 \%$ atau 0,05$)$

\section{Kata kunci : Pelayanan, Kepuasan, Loyalitas, Nasabah}

\section{RENDAHULUAN}

\subsection{Iatar Belakang Penelitian}

BPR adalah lembaga keuangan mikro dimana pada saat ini kredit mikro yang disalurkan oleh bank besar yaitu bank umum justru mengambil pangsa pasar kredit yang selama ini dibiayai oleh BPR. Namum, betapapun tangguhnya BPR akan tetap sulit bersaing dengan bank umum, baik dalam menghimpun dana masyarakat maupun dalam menyalurkan kreditnya. Dengan masuknya bank asing ke indonesia untuk turut serta membiayai pada sektor mikro menjadikan pangsa pasar kredit mikro untuk BPR lambat laun terus mengalami penurunan.

Pentingnya pelayanan untuk memenangkan persaingan menjadii penentu keberhasilan BPR. Karena dengan pelayanan yang prima akan memenuhi harapan nasabah sehingga nasabah menjadi puas, menceritakannya kepada masyarakat atau lingkungan di sekitar tempat tinggalnya yang merupakan pemasaran yang paling efektif yaitu word of mouth (mulut ke mulut) dan ini merupakan kekuatan dari pelayanan sehingga membentuk loyalitas atau kesetiaan pada nasabah dan nasabah tidak mudah lari atau berpindah ke tempat lain.

\subsection{Rumusan Masalah}

1. Bagaimana pengaruh pelayanan terhadap tingkat kepuasan nasabah kredit di PT. BPR Naribi Perkasa ?

2. Seberapa besar pengaruh 
antara pelayan dan kepuasan

3. nasabah terhadap loyalitas nasabah di PT. BPR X ?

4. Seberapa besar pengarh pelayanan dan kepuasan terhadap loyalitas nasabah di PT. BPR X ?

\subsection{Tujuan Penelitian}

1. Untuk mengetahui dan menganalisis pengaruh pelayanan terhadap tingkat kepuasan nasabah kredit di PT. BPR X.

2. Untuk mengetahui dan menganalisis pengaruh antara kepuasan terhadap loyalitas nasabah kredit pada PT. BPR X

\section{METODE PENELITIAN}

2.1 Teknik Pengumpulan Data

Pengumpulan data menggunakan observasi lapangan, interview/wawancara dengan pihak yang terkait dengan penelitian dan menyebarkan kuesioner kepada responden.

\subsection{Kerangka Pemikiran Teoritis}

Kerangka pemikiran sebagai berikut :

Gambar 2.1

Kerangka Pemikiran

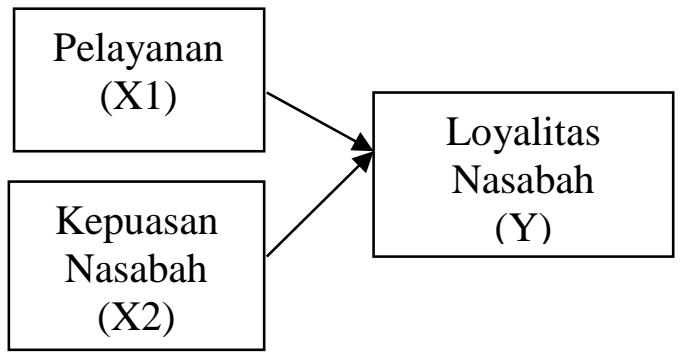

3. Untuk mengetahui dan menganalisis pengaruh antara pelayanan dan kepuasan terhadap loyalitas nasabah kredit di PT. BPR $\mathrm{X}$.

\subsection{Hipotesis}

1. Terdapat pengaruh positif dan signifikan antara variable pelayanan dan loyalitas nasabah.

2. Terdapat pengaruh positif dan signifikan antara variable kepuasan dan loyalitas nasabah.

3. Terdapat pengaruh positif dan signifikan antara variable pelayanan dan kepuasan dan loyalitas nasabah.

\subsection{Identifikasi}

Variabel Penelitian

Variabel independen/bebas $(\mathrm{X} 1=$ Pelayanan $), \quad(\mathrm{X} 2=$ Kepuasan)

Variabel Dependen/terikat ( $\mathrm{Y}=$ Loyalitas).

\subsection{Populasi dan Sampel}

Populasi adalah nasabah kredit dari PT. Bank Naribi Perkasa cabang utama Depok yaitu 386 orang, menggunakan teknik purposive sampling dengan kriteria yang sudah menjadi nasabah kredit, maka sample yang diambil sekitar 15\% dari populasi yaitu 60 responden.

\subsection{Teknik Analisis Data}

\section{Uji Validitas Instrumen}

Jika $r_{\text {hitung }}>r_{\text {tabel }}$ maka pertanyaan dinyatakan valid dan jika berlaku hal sebaliknya pertanyaan dinyatakan tidak valid dan tidak diikut sertakan pada perhitungan selanjutnya.. 


\section{Uji Reliabilitas}

Metode yang digunakan untuk mengukur reliabilitas dengan menggunakan rumus Cronbach Alpha. Suatu instrumen dikatakan reliable jika nilai reliabilitas $>0,700$.

3. Analisis Regresi Linier Berganda

Regresi linear berganda sebagai berikut :

$\mathrm{Y}=\mathrm{a}+\mathrm{b}_{1} \mathrm{X}_{1}+\mathrm{b}_{2} \mathrm{X}_{2}$

Ket : Y : Loyalitas

Nasabah, a : Konstanta, 6 :

Koefisien Regresi, Xi :

Pelayanan,

X2 : Kepuasan Nasábah,

$a$ : Konstanta, $b$ : Koefisien

Regresi

4. Analisis Koefisien Korelasi

(r)

Digunakan untuk mengukur tingkat keeratan hubungan antara semua variabel bebas vaitu pelayanan dan kepuasan terhadap variabel terikat yaitu loyalitas.

Rumus :

$$
r_{x y}=\frac{\sum X Y}{\sqrt{\left(\sum X^{2} Y^{2}\right)}}
$$

5. Koefisien Determinasi

Sederhana $\left(\mathbf{r}^{2}\right)$

$\mathrm{KD}=\mathrm{r}^{2}$

$r=\sqrt{ } r^{2}$

Ket:KD=Koefisien

dterminasi, $r=$ Koefisien korelasi

6. Uji t (Uji Parsial)

Uji t digunakan mengetahui apakah variabel bebas secara parsial mempunyai pengaruh yang signifikan terhadap variabel terikat.

\section{Uji F (Uji Serentak)}

Uji $F$ digunakan untuk menguji tingkat signifikansi koefisien regresi variabel bebas secara serempak terhadap variabel terikat. Dengan kriteria pengujiannya Ho diterima jika $\mathrm{F}$ hitung $<\mathrm{F}$ tabel dan Ho ditolak jika $F$ hitung > F tabel

1. Identitas Responden yang meliputi :

a. Berdasarkan gender

\section{ANALISIS DAN PEMBAHASAN}

\subsection{Deskripsi Data}

Berikut ini adalah deskripsi hasil dari pengolahan dan analisa karakteristik responden : 
Tabel 3.1

Gender

\begin{tabular}{|c|l|c|c|}
\hline \multirow{2}{*}{ No } & \multirow{2}{*}{ Gender } & \multicolumn{2}{|c|}{ Jumlah } \\
\cline { 3 - 4 } & & Angka & Persentase \% \\
\hline 1 & Pria & 45 & $75 \%$ \\
\hline 2 & Wanita & 15 & $25 \%$ \\
\hline \multicolumn{2}{|c|}{ Jumlah } & 60 & $100 \%$ \\
\hline
\end{tabular}

Sumber : diolah dari daftar pertanyaan

dari data diatas yang berjenis kelamin laki-laki 45 orang (75\%) sedangkan yang berjenis kelamin perempuan 15 orang $(25 \%)$. Berdasarkan data

tersebut dapat disimpulkan bahwa dari 60 yang mengisi kuisioner jumlah responden laki -laki yang mendominasi berjumlah 45 orâng atau sebesar $75 \%$.

b. Berdasarkan Usia Responden

Tabel 3.2

Umur

\begin{tabular}{|c|l|c|c|}
\hline No & \multicolumn{2}{|c|}{ Umur } \\
\hline 1 & $<20$ thn \\
\hline 2 & $20-35$ thn \\
\hline 3 & $36-50$ thn \\
\hline 4 & $>50$ thn \\
\hline
\end{tabular}

Sumber : diolah dari daftar pertanyaan

Dari tabel diatas menunjukan responden umur antara 20 sampai dengan 35 tahun berjumlah 11 orang (18\%), yang memiliki usia antara 36 sampai dengan 50 tahun berjumlah 31 orang ( $52 \%$ ), berusia diatas 50 tahun berjumlah 18 orang $(30 \%)$ dan tidak ada yang berusia dibawah 20 tahun, jadi dapat disimpulkan bahwa responden pada umumnya lebih banyak berusia di atas 35 tahun dengan jumlah 31 orang atau sebesar $52 \%$ berarti cukup matang berdasarkan dari segi usia.

c. Berdasarkan Status Perkawinan Responden 
Tabel 3.3

Status Perkawinan

\begin{tabular}{|c|l|c|c|}
\hline \multirow{2}{*}{ No } & \multirow{2}{*}{ Status Perkawinan } & \multicolumn{2}{|c|}{ Jumlah } \\
\cline { 3 - 4 } & & Angka & Persentase \% \\
\hline 1 & Lajang & 6 & $10 \%$ \\
\hline 2 & Menikah & 51 & $85 \%$ \\
\hline 3 & Janda/Duda & 3 & $5 \%$ \\
\hline \multicolumn{2}{|c|}{ Jumlah } & 60 & $100 \%$ \\
\hline
\end{tabular}

Sumber : diolah dari daftar pertayaan

berjumlah 6 orang $(10 \%)$ yang

Dari tabel diatas menunjukan bahwa responden yang masih belum menikah/lajang sudah menikah berjumlah 51 orang $(85 \%)$ dan Ianda/duda berjumlah 3 orang $(5 \%)$.

d. Berdasarkan Pendidikan

Tabel 3.4

Pendidikan

\begin{tabular}{|c|l|c|c|}
\hline \multirow{2}{*}{ No } & \multirow{2}{*}{ Pendidikan } & \multicolumn{2}{|c|}{ Jumlah } \\
\hline 1 & S SMA \\
\hline 2 & SMA/SMK & 6 & Angka \\
\hline 3 & Universitas & 35 & $58 \%$ \\
\hline & Jumlah & 19 & $32 \%$ \\
\hline
\end{tabular}

Sumber: diolah dari daftar pertayaan

Dari tabel diats terlihat bahwa responden yang memiliki latar belakang pendidikan dibawah SMA berjumlah 6 orang $(10 \%)$ tingkat pendidikan sampai dengan SMA/SMK berjumlah

e. Berdasarkan Profesi Responden
35 orang $(58 \%)$ dan yang memiliki latar belakang tingkat pendidikan diatas SMA atau tingkatan Universitas berjumlah 19 orang (32\%). 
Tabel 3.5

Profesi

\begin{tabular}{|c|l|c|c|}
\hline \multirow{2}{*}{ No } & \multicolumn{2}{|c|}{ Profesi } & \multicolumn{2}{|c|}{ Jumlah } \\
\cline { 3 - 4 } & & Angka & Persentase \% \\
\hline 1 & Swasta & 24 & $40 \%$ \\
\hline 2 & PNS & 10 & $17 \%$ \\
\hline 3 & Wiraswasta/Usaha Sendiri & 25 & $42 \%$ \\
\hline 4 & Pensiunan & 1 & $2 \%$ \\
\hline \multicolumn{2}{|c|}{ Jumlah } & 60 & $100 \%$ \\
\hline
\end{tabular}

Sumber : diolah dari daftar pertayaan

Tabel tersebut menunjukan bahwa responden yang memiliki profesi sebagai karyawan swasta berjumlah 24 orang atau sebesar $40 \%$, yang memiliki profesi sebagai pegawai negeri berjumlah 10 orang $(17 \%)$ responden yang berwiraswasta atau memiliki usaha sendiri berjumlah 25 orang $(42 \%)$ dan responden yang pensiunan berjumiah 1 orang $(2 \%)$ disimpulkan bahwa responden rata-rata lebih banyak berprofesi sebagai karyawan swasta dan berwirausaha. berarti mempunyai sumber penghasilan yang cukup memadai sebagai sumber pengembalian kredit yang cukup jelas.

f. Pendapatan Perbulan

Tabel 3.6

Pendapatan Perbulan

\begin{tabular}{|c|c|c|c|}
\hline \multirow{2}{*}{ No } & \multirow{2}{*}{$\begin{array}{c}\text { Pendapatan } \\
\text { (Rp) }\end{array}$} & \multicolumn{2}{|c|}{ Jumlah } \\
\hline & & Angka & Persentase $\%$ \\
\hline 1 & S1,5 Juta & 6 & $10 \%$ \\
\hline 2 & $1,5,2$ Juta & 11 & $18 \%$ \\
\hline 3 & $2-3$ Juta & 11 & $18 \%$ \\
\hline 4 & 3 - 5 Juta & 24 & $40 \%$ \\
\hline 5 & $>5$ Juta & 8 & $13 \%$ \\
\hline & Jumlah & 60 & $100 \%$ \\
\hline
\end{tabular}

Sumber : diolah dari daftar pertayaan

Dari tabel di atas terlihat responden yang memiliki pendapan perbulan kurang dari 1,5 juta berjumlah 6 orang $(10 \%)$ responden yang memiliki pendapatan perbulan 1,5-2 juta berjumlah 11 orang (18\%) responden yang memiliki pendapatan perbulan sebesar 2-3 juta berjumlah 11 orang (18\%) responden yang memiliki pendapatan perbulan 3-5 juta berjumlah 24 orang (40\%) dan responden yang memiliki pendapatan perbulan diatas 5 juta berjumlah 8 orang $(13 \%)$. Berdasarkan data tersebut disimpulkan bahwa jumlah responden yang memiliki penghasilan rata-rata 
perbulan diatas 3-5 juta dengan jumlah 24 orang (40\%) berarti memiliki penghasilan yang

\subsection{Uji Validitas Instrumen}

Tujuan dilakukannya Uji validitas pada data yang digunakan adalah untuk keyakinkan bahwa cukup sebagai sumber pengembalian pembayaran angsuran kredit.

Tabel 3.7

Uji validitas variabel pelayanan correlations

\begin{tabular}{|c|c|c|c|c|c|c|c|c|c|c|c|c|}
\hline & & $\times 1 \_1$ & $X_{1}{ }_{2} 2$ & $x 13$ & $\times 1.4$ & $\times 1.5$ & $X 16$ & $x 1 / 7$ & 0 & $x_{1}$ & NI 10 & $\begin{array}{c}X 1 \\
\text { Pelayanan }\end{array}$ \\
\hline \multirow[t]{3}{*}{$\overline{X 1 \_1}$} & Pearson Correlation & 1 & $.255^{\prime}$ & $.358^{\prime \prime}$ & $.428^{\prime \prime}$ & $.335^{\prime \prime}$ & .144 & .175 & 146 & .052 & .046 & $.489^{\prime \prime}$ \\
\hline & Sig. (2-tailed) & & .049 & .005 & .001 & .009 & 73 & .80 & & & .729 & .000 \\
\hline & N & 60 & 60 & 60 & 60 & 60 & 60 & 60 & 50 & 60 & 60 & 60 \\
\hline \multirow[t]{3}{*}{ X1_2 } & Pearson Correlation & $.255^{\prime}$ & 1 & $.444^{\prime \prime}$ & $.421 "$ & $527^{\prime \prime}$ & .208 & .043 & .067 & .087 & .051 & $.540^{\prime \prime}$ \\
\hline & Sig. (2-tailed) & .049 & & .000 & .001 & 000 & .111 & .744 & .812 & .510 & .701 & .000 \\
\hline & N & 60 & 60 & 60 & 60 & 60 & 60 & 60 & 60 & 60 & 60 & 60 \\
\hline \multirow[t]{3}{*}{$\mathrm{X} 1 \_3$} & Pearson Correlation & $.358^{\prime \prime}$ & $444 "$ & 1 & $530 "$ & $.411 "$ & .010 & .005 & .096 & -.018 & $-314^{\prime}$ & $432^{\prime \prime}$ \\
\hline & Sig. (2-tailed) & .005 & .000 & & & 001 & .938 & .968 & .465 & .894 & .015 & .001 \\
\hline & N & 60 & 60 & 60) & 60 & 60 & 60 & 60 & 60 & 60 & 60 & 60 \\
\hline \multirow[t]{3}{*}{ X1_4 } & Pearson Correlation & $.428^{\prime \prime}$ & $421^{7}$ & & 1 & $.616^{\prime \prime}$ & .122 & .108 & .084 & .070 & -.127 & $.575^{\prime \prime}$ \\
\hline & Sig. (2-tailed) & .001 & & & & 000 & .353 & .413 & .523 & .596 & .334 & .000 \\
\hline & N & 6in & 60 & 50 & 60. & 60 & 60 & 60 & 60 & 60 & 60 & 60 \\
\hline \multirow[t]{3}{*}{ X1_5 } & Pearson Correlation & $335^{\prime \prime}$ & $52 \mathrm{r}^{\prime \prime}$ & 4111 & $616 "$ & 1 & .210 & .040 & .102 & .073 & -.097 & $.554^{\prime \prime}$ \\
\hline & Sig. (2-tailed) & toog & .000 & .001 & .000 & & .107 & .764 & .437 & .580 & .459 & .000 \\
\hline & $N$ & 60 & 80 & 60 & 60 & 60 & 60 & 60 & 60 & 60 & 60 & 60 \\
\hline \multirow[t]{3}{*}{$\mathrm{X} 1 \_6$} & Pearson correlation & .144 & .208 & .010 & .122 & .210 & 1 & $.774 "$ & $.634^{\prime \prime}$ & $.553^{\prime \prime}$ & $.430^{\prime \prime}$ & $.741^{\prime \prime}$ \\
\hline & & .273 & & .938 & .353 & .107 & & .000 & .000 & .000 & .001 & .000 \\
\hline & N & 60 & 60 & 60 & 60 & 60 & 60 & 60 & 60 & 60 & 60 & 60 \\
\hline \multirow[t]{3}{*}{ X1_? } & Pearson Correlation & .175 & .043 & .005. & .108 & .040 & $.774^{\prime \prime}$ & 1 & $.568^{\prime \prime}$ & $.533^{\prime \prime}$ & .252 & $.643^{\prime \prime}$ \\
\hline & Sig. (2-tailed) & .180 & .744 & .968 & .413 & .764 & .000 & & .000 & .000 & .052 & .000 \\
\hline & N & 60 & 60 & 60 & 60 & 60 & 60 & 60 & 60 & 60 & 60 & 60 \\
\hline \multirow[t]{3}{*}{$x 18$} & Pearson Correlation & .146 & .067 & .096 & .084 & .102 & $.634^{\prime \prime}$ & $.568^{\prime \prime}$ & 1 & $.729^{\prime \prime}$ & $.356 "$ & $.666 "$ \\
\hline & Sig. (2-tailed) & .266 & .612 & .465 & .523 & .437 & .000 & .000 & & .000 & .005 & .000 \\
\hline & N $/$ & 60 & 60 & 60 & 60 & 60 & 60 & 60 & 60 & 60 & 60 & 60 \\
\hline \multirow{3}{*}{ X1_g } & Pearson Correlation & .052 & .087 & -.018 & .070 & .073 & $.553^{\prime \prime}$ & $.533^{\prime \prime}$ & $.729^{\prime \prime}$ & 1 & $470^{\prime \prime}$ & $.625^{\prime \prime}$ \\
\hline & Sig. (2-tailed) & .694 & .510 & .894 & .596 & .580 & .000 & .000 & .000 & & .000 & .000 \\
\hline & N & 60 & 60 & 60 & 60 & 60 & 60 & 60 & 60 & 60 & 60 & 60 \\
\hline \multirow[t]{3}{*}{ X1_10 } & Pearson Correlation & -.046 & .051 & $-314^{\prime}$ & -.127 & -.097 & $.430^{\prime \prime}$ & .252 & $.356 "$ & $.470^{\prime \prime}$ & 1 & $.372^{\prime \prime}$ \\
\hline & Sig. (2-tailed) & .729 & .701 & .015 & .334 & .459 & .001 & .052 & .005 & .000 & & .003 \\
\hline & $N$ & 60 & 60 & 60 & 60 & 60 & 60 & 60 & 60 & 60 & 60 & 60 \\
\hline \multirow[t]{3}{*}{ X1_Pelayanan } & Pearson Correlation & $.489^{\prime \prime}$ & $.540^{\prime \prime}$ & $.432 "$ & $.575^{\prime \prime}$ & $.554^{\prime \prime}$ & $.741^{\prime \prime}$ & $.643^{\prime \prime}$ & $.666 "$ & $.625^{\prime \prime}$ & $.372^{\prime \prime}$ & 1 \\
\hline & Sig. (2-tailed) & .000 & .000 & .001 & .000 & .000 & .000 & .000 & .000 & .000 & .003 & \\
\hline & $N$ & 60 & 60 & 60 & 60 & 60 & 60 & 60 & 60 & 60 & 60 & 60 \\
\hline
\end{tabular}


Tabel 3.8

Uji validitas variable kepuasan

\begin{tabular}{|c|c|c|c|c|c|c|}
\hline \multicolumn{7}{|c|}{ Correlations } \\
\hline & & $\mathrm{Y} 1$ & Y2 & Y3 & $Y_{4}$ & Y_Loyalitas \\
\hline \multirow[t]{3}{*}{ Y1 } & Pearson Correlation & 1 & $.469^{-1}$ & $.544^{-1}$ & $.362^{-1}$ & $.718^{-}$ \\
\hline & Sig. (2-tailed) & & .000 & .000 & .004 & .000 \\
\hline & $\mathrm{N}$ & 60 & 60 & 60 & & 60 \\
\hline \multirow[t]{3}{*}{$\mathrm{Y} 2$} & Pearson Correlation & $.469^{-}$ & 1 & $95^{-1}$ & in & $.844^{-}$ \\
\hline & Sig. (2-tailed) & .000 & & & 00 & .000 \\
\hline & $\mathrm{N}$ & 60 & 60 & & 60 & 60 \\
\hline \multirow[t]{3}{*}{ Y3 } & Pearson Correlation & $.544^{-1}$ & $95 \sqrt{-1}$ & & & $.848^{-}$ \\
\hline & Sig. (2-tailed) & .000 & & & & .000 \\
\hline & $\mathrm{N}$ & 60 & 0 & 60 & 60 & 60 \\
\hline \multirow[t]{3}{*}{ Y4 } & Pearson Correlation & & & $589^{4}$ & 1 & $.821^{-}$ \\
\hline & Sig. (2-tailed) & & & .000 & & .000 \\
\hline & $\mathrm{N}$ & & 60 & 60 & 60 & 60 \\
\hline Y_Loyalitas & Pearson Correlation & $.718^{-1}$ & $.844^{-1}$ & $.848^{-1}$ & $.821^{-1}$ & 1 \\
\hline & $\begin{array}{l}\text { Sig. (2-tailed) } \\
\mathrm{N}\end{array}$ & 60 & $\begin{array}{r}.000 \\
60\end{array}$ & $\begin{array}{r}.000 \\
60\end{array}$ & $\begin{array}{r}.000 \\
60\end{array}$ & 60 \\
\hline
\end{tabular}

**. Correlation is significant at the 0.0.1 level (2-tailed).

Tabel 3.9

Uji validitas variable loyalitas

\begin{tabular}{|c|c|c|c|c|c|c|c|}
\hline \multicolumn{8}{|c|}{ Correlations } \\
\hline & $=$ & $\times 2 \_1$ & $\times 2 \_2$ & $\times 2 \_3$ & $\times 2 \_4$ & $\times 2 \_5$ & X2_Kepuasan \\
\hline & $\begin{array}{l}\text { on Corre } \\
\text {-tailed) }\end{array}$ & $\begin{array}{r}1 \\
60 \\
\end{array}$ & $\begin{array}{r}.628 \\
.000 \\
60 \\
\end{array}$ & $\begin{array}{r}.650^{-} \\
.000 \\
60 \\
\end{array}$ & $\begin{array}{r}.726 \\
.000 \\
60 \\
\end{array}$ & $\begin{array}{r}.620^{-} \\
.000 \\
60 \\
\end{array}$ & $\begin{array}{r}.896 \\
.000 \\
60\end{array}$ \\
\hline$\times 2{ }^{2} 2$ & $\begin{array}{l}\text { Pearson Correlation } \\
\text { Sig.(2-tailed) } \\
\mathrm{N}\end{array}$ & $\begin{array}{r}.628 \\
.000 \\
60 \\
\end{array}$ & 60 & $\begin{array}{r}.566 \\
.000 \\
60 \\
\end{array}$ & $\begin{array}{r}.505 \\
.000 \\
60\end{array}$ & $\begin{array}{r}.484 \\
.000 \\
60 \\
\end{array}$ & $\begin{array}{r}.785^{-} \\
.000 \\
60\end{array}$ \\
\hline$\times 2{ }^{2} 3$ & $\begin{array}{l}\text { Pearson Correlation } \\
\text { Sig. (2-tailed) } \\
\mathrm{N}\end{array}$ & $\begin{array}{r}.650^{-} \\
.000 \\
60\end{array}$ & $\begin{array}{r}.566 \\
.000 \\
60\end{array}$ & $\begin{array}{r}1 \\
60\end{array}$ & $\begin{array}{r}.698^{-} \\
.000 \\
60\end{array}$ & $\begin{array}{r}.373^{-} \\
.003 \\
60\end{array}$ & $\begin{array}{r}.822 \\
.000 \\
60\end{array}$ \\
\hline$\times 2 \_4$ & $\begin{array}{l}\text { Pearson Correlation } \\
\text { Sig. (2-tailed) } \\
\mathrm{N}\end{array}$ & $\begin{array}{r}.726 \\
.000 \\
60 \\
\end{array}$ & $\begin{array}{r}.505 \\
.000 \\
60 \\
\end{array}$ & $\begin{array}{r}.698^{-} \\
.000 \\
60 \\
\end{array}$ & $\begin{array}{r}1 \\
60 \\
\end{array}$ & $\begin{array}{r}.394 \\
.002 \\
60 \\
\end{array}$ & $\begin{array}{r}.820^{-} \\
.000 \\
60 \\
\end{array}$ \\
\hline$\times 2 \_5$ & $\begin{array}{l}\text { Pearson Correlation } \\
\text { Sig. (2-tailed) } \\
\mathrm{N}\end{array}$ & $\begin{array}{r}.620^{-} \\
.000 \\
60 \\
\end{array}$ & $\begin{array}{r}.484 \\
.000 \\
60 \\
\end{array}$ & $\begin{array}{r}.373 \\
.003 \\
60 \\
\end{array}$ & $\begin{array}{r}.394 \\
.002 \\
60 \\
\end{array}$ & $\begin{array}{r}1 \\
60 \\
\end{array}$ & $\begin{array}{r}.712 \\
.000 \\
60 \\
\end{array}$ \\
\hline X2_Kepuasan & $\begin{array}{l}\text { Pearson Correlation } \\
\text { Sig. (2-tailed) } \\
\mathrm{N}\end{array}$ & $\begin{array}{r}.896 \\
.000 \\
60 \\
\end{array}$ & $\begin{array}{r}.785 \\
.000 \\
60 \\
\end{array}$ & $\begin{array}{r}.822 \\
.000 \\
60 \\
\end{array}$ & $\begin{array}{r}.820 \\
.000 \\
60 \\
\end{array}$ & $\begin{array}{r}.712 \\
.000 \\
60 \\
\end{array}$ & 60 \\
\hline
\end{tabular}

**. Correlation is significant at the 0.01 level (2-tailed).

\subsection{Uji Reliabilitas}

Salah satu metode yang dapat dipakai untuk mengukur reliabilitas dengan menggunakan rumus

Cronbach Alpha.Suatu instrumen 
dikatakan reliable jika nilai reliabilitas $>0,700$

Tabel 3.10

Uji Reliabilitas Instrumen Variabel X1,X2 dan Y1

\begin{tabular}{|c|l|c|c|c|}
\hline NO & \multicolumn{1}{|c|}{ Variabel } & Alpha Cronbach's & Batas min & Reliabilitas \\
\hline 1. & Pelayanan (x1) & 0.800 & 0.700 & Reliable \\
\hline 2. & Kepuasan (x2) & 0.910 & 0.700 & Reliable \\
\hline 3. & Loyalitas (y) & 0.894 & 0.700 & Reliable \\
\hline
\end{tabular}

\subsection{Uji Normalitas Instrumen}

Uji normalitas merupakan uji asumsi klasik, salah satu bagian dari uji persyaratan analisis data atau uji artinya sebelum kita melakukan analisis yang sesungguhnya, data penelitian tersebut harus di uji kenormalan distribusinya. Data yang baik itu adalah data yang normal dalam pendistribusiannya.

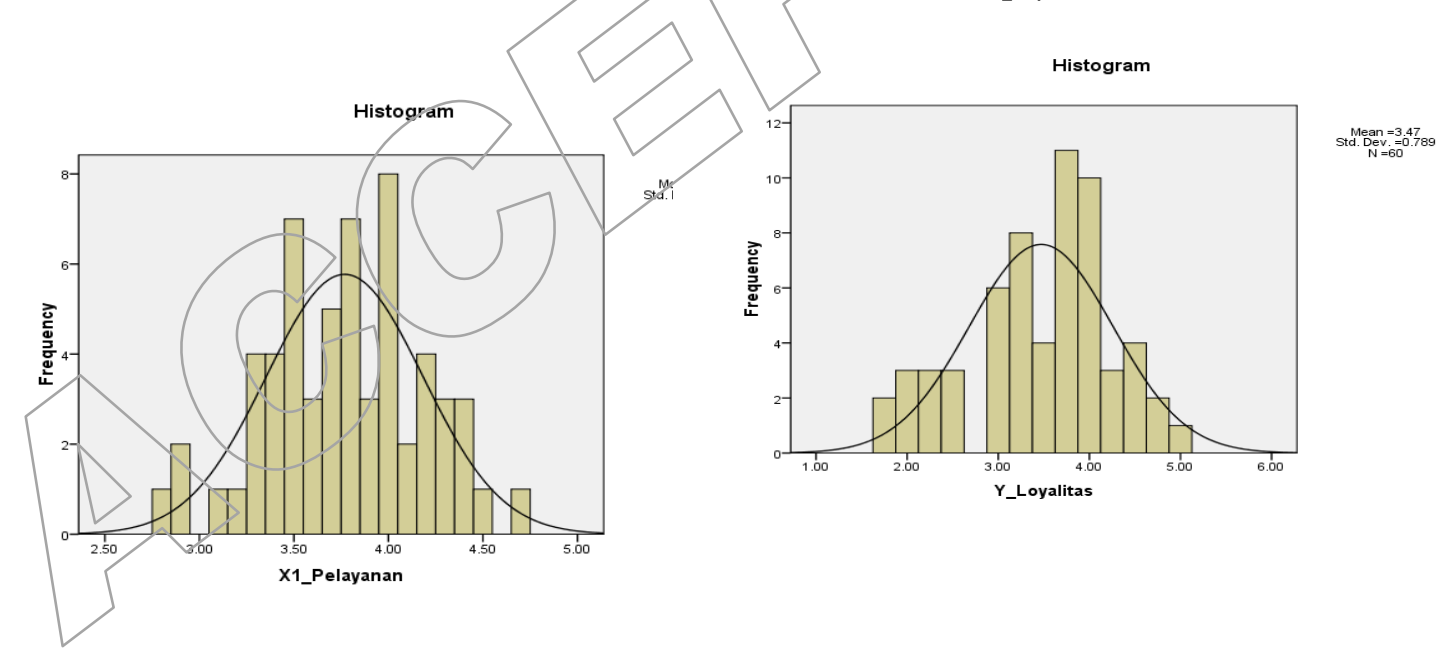

\subsection{Uji Regresi linier berganda}


Tabel 3.11

Uji regresi linier berganda

\begin{tabular}{|c|c|c|c|c|c|c|}
\hline \multicolumn{7}{|c|}{ koefisien $^{a}$} \\
\hline & \multirow[b]{2}{*}{ Model } & \multicolumn{2}{|c|}{ Unstandardized koefisien } & \multirow{2}{*}{$\begin{array}{c}\begin{array}{c}\text { Standard } \\
\text { koefisien }\end{array} \\
\text { Beta }\end{array}$} & \multirow[b]{2}{*}{$\mathrm{t}$} & \multirow[b]{2}{*}{ Signifikansi } \\
\hline & & $\mathrm{B}$ & Std. Error & & & \\
\hline \multirow{3}{*}{1} & (konstanta) & .245 & .836 & & .294 & .770 \\
\hline & X1_Pelayanan & .474 & .219 & .249 & 2.169 & .034 \\
\hline & X2_Kepuasan & .445 & .122 & .420 & 3.653 & .001 \\
\hline
\end{tabular}

a. Dependent Variable: Y_Loyalitas

Berdasarkan tabel di atas persamaan regresi linier berganda sebagai berikut :

$\mathrm{Y}=\mathrm{a}+\mathrm{b} 1 \mathrm{X} 1+\mathrm{b} 2 \mathrm{X} 2+\mathrm{e}$

$\mathrm{Y}=0,245+0,474 \mathrm{X} 1+0,445 \mathrm{X} 2$

yang berarti tanpa adanya veriabel $X 1$ (pelayanan) dan X2 (kepuasan) maka variable Y (kepuasan) tetap sebesar 0,254, namun jika terjadi kenaikan sebesar satu satuan pada variable $\mathrm{x} 1$ dan x2 maka akan meningkatkan variable y sebesar $0,245+0,445$ $=0,69$.

Hasil regresi linier berganda di atas menunjukkan bahwa variabel pelayanan $(X 1)$ dan kepuasan nasabah $(X 2)$ berpengaruh positif terhadap variabel Loyalitas (Y).

\subsection{Analisis koefesien korelasi dan determinasi}

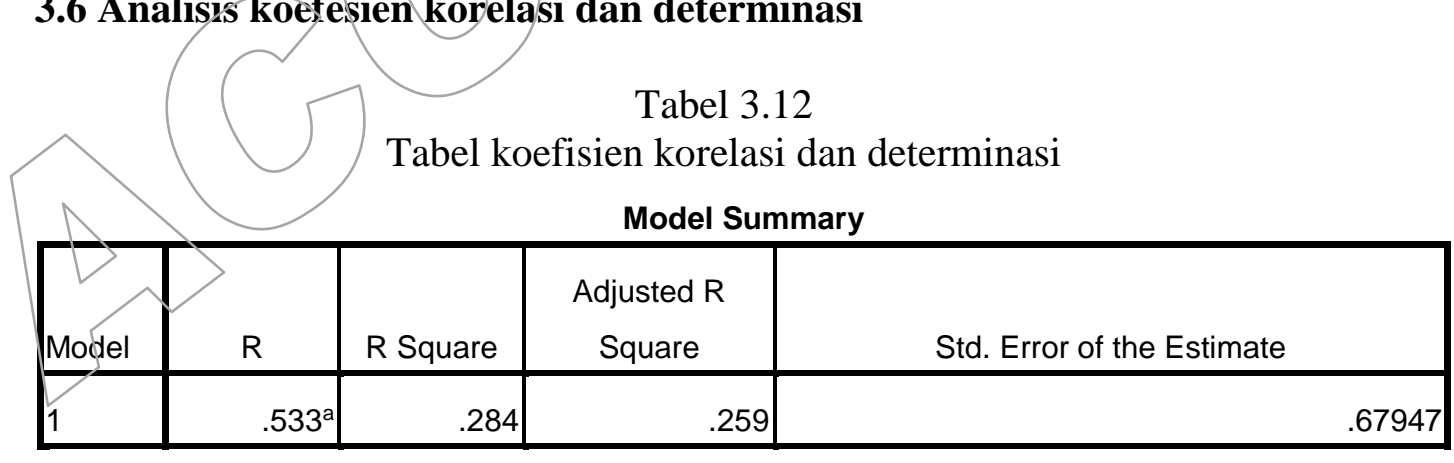

a. Predictors: (Constant), X2_Kepuasan, X1_Pelayanan

Dari tabel diatas $(\mathrm{R}=0,533)$ artinya variabel bebas mempunyai hubungan yang cukup kuat dengan variabel terikat sedangkan koefisien determinasi ( $\mathrm{R}$ Square) sebesar 0,284 yang artinya variabel bebas Pelayanan dan kepuasan mempengaruhi variabel terikat loyalitas sebesar $28,4 \%$ sisanya sebesar 71,6\% dipengaruhi variabel bebas lainnya yang tidak termasuk dalam penelitian ini yaitu tingkat persaingan, permintaan pasar, harga, promosi, dan lain-lain. 


\subsection{Uji T Parsial}

Tabel 3.13

Tabel T

koefisien $^{\mathrm{a}}$

\begin{tabular}{|c|c|c|c|c|c|c|}
\hline & \multirow[b]{2}{*}{ Model } & \multicolumn{2}{|c|}{ Unstandardized koefisien } & \multirow{2}{*}{$\begin{array}{c}\text { Standardized } \\
\text { koefisien }\end{array}$} & \multirow[b]{2}{*}{$\mathrm{T}$} & \multirow[b]{2}{*}{ Signifikansi } \\
\hline & & $B$ & Std. Error & & & \\
\hline \multirow{3}{*}{1} & (konstantat) & .245 & .836 & & .294 & .770 \\
\hline & X1_Pelayanan & .474 & .219 & .249 & 2.169 & .034 \\
\hline & X2_Kepuasan & .445 & .122 & .420 & 3.653 & .001 \\
\hline
\end{tabular}

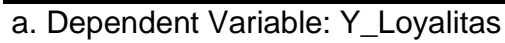

\section{Variabel Pelayanan (X1)}

Dari tabel diatas nilai t-hitung variabel pelayanan $(2,169)>\mathrm{t}$-tabel (1,671) maka $\mathrm{H}_{0}$ ditolak dan $\mathrm{H}_{1}$ diterima, Artinya bahwa variabel pelayanan mempunyai pengaruh terhadap loyalitas, dengan nilai signifikansi sebesar 0,034 karena nilai signifikansi dibawah 0,05 maka hal tersebut menunjukan bahwa variabei pelayanan berpengaruh tidak signifikan terhadap løyalitas

Variabel kepuasan nasabah (X2) dari tabel diatas diperoleh nilai $\mathrm{t}$ hitung variabel kepuasan rasabah $(3,653)>$ t-tabel $(1,671)$ maka $\mathrm{H}_{0}$ ditolak dan $\mathrm{H}_{1}$ diterima. Berarti variabel kepuasan nasabah mempunyai pengaruh terhadap Loyalitas. Dan dengan nilai signifikansi sebesar 0,001 karena nilai signifikansi di bawah 0,05 maka hal tersebut menunjukan bahwa variabel kepuasan nasabah berpengaruh secara tidak signifikan terhadap loyalitas.

\section{$3.8 \mathrm{Uji}$

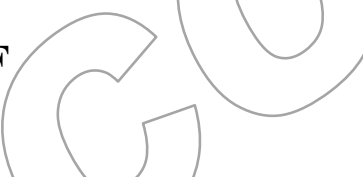 \\ Tabel 3.14 \\ Tabel uji $\mathrm{F}$ \\ ANOVA $^{b}$ \\ a. Predictors: (Constant), X2_Kepuasan, X1_Pelayanan \\ b. Dependent Variable: Y_Loyalitas}

\begin{tabular}{|l|r|r|r|r|r|}
\hline$\sum$ Model & Sum of Squares & Df & Mean Square & F & Signifikansi \\
\hline 1 & 10.446 & 2 & 5.223 & 11.313 & $.000^{a}$ \\
Regression & 26.316 & 57 & .462 & & \\
Residual & 36.761 & 59 & & & \\
Total & & & & \\
\hline
\end{tabular}

Berdasarkan tabel di atas bahwa tingkat signifikan yang diperoleh adalah $(0,000)$ nilai ini dapat dikatakan mutlak signifikan karena bernilai 0,000 dan lebih kecil dari standar signifikan $(5 \%$ atau 0,05$)$.
Nilai $F_{\text {hitung }}$ dari semua variabel bebas pelayanan dan kepuasan nasabah sebesar 11.313 lebih besar dari $F_{\text {tabel }}$ yaitu sebesar 2,370 sehingga dapat disimpulkan bahwa Ho ditolak dan $\mathrm{H}_{1}$ diterima artinya pelayanan dan 
kepuasan nasabah memiliki pengaruh yang signifikan terhadap Loyalitas.

\section{KESIMPULAN DAN SARAN}

\subsection{Kesimpulan}

1. Dari hasil uji regresi linier berganda memperlihatkann bahwa variabel pelayanan dan kepuasan nasabah memiliki hubungan yang positif dengan variabel Loyalitas.

2. koefisien korelasi menunjukkan nilai korelasi yang diperoleh untuk penelitian ini sebesar 0,533 masuk dalam interval antara $(0,40-0,599)$ sehingga dapat disimpulkan bahwa variabel pelayanan dan kepuasan nasabah dengan variabel loyalitas berkorelasi cukup kuat.

3. Korelasi antara pelayanan dan kepuasan nasabah terhadap loyalitas menunjukkan angka positif yang berarti bahwa semakin aktif perusahaan melakukan perbaikan pelayanan dan peningkatan kepuasan nasabah maka semakin tinggi tingkat loyalitas nasabah.

4. Koefisien determinasi (R Square) sebesar 0,284 yang berarti $28,4 \%$ variabel bebas, pelayanan dan kepuasan mampu menjelaskan terhadap variabel loyaslitas, sedangkan sisanya $71,6 \%$ dipengaruhi variabel bebas lainnya yang tidak termasuk dalam penelitian ini yaitu tingkat persaingan, permintaan pasar, harga, promosi, dan lainnya.

\subsection{Saran}

1. Pihak manajemen PT.Bank Naribi Perkasa lebih meningkatkan perhatian terhadap Pelayanan(X1) Kepuasan nasabah (X2) agar Nasabah menjadi loyal sebagai nasabah kredit .

2. PT. BPR X harus lebih aktif melakukan perbaikan pelayanan dan peningkatan kepuasan nasabah maka semakin tinggi tingkat loyalitas nasabah.

3. PT.BPR Naribi perkasa perlu mempertimbangkan factorfaktor lain dalam meiningkatkan loyalitas yaitu tingkat persaingan, permintaan pasar, harga, promosi, dan lainnya. 


\section{DAFTAR PUSTAKA}

[1] Anatan,Lina. 2008. Service Excellence Competing Through Competitiveness. Bandung : Alfabeta.

[2] Endersheim, Elizabeth Haas. 2008. The Definitive Drucker. Jakarta : Bhuana Ilmu Populer.

[3] Joseph Cannon P., Perreault William D. dan McCarthy Jr., E. Jerome. 2008. Pemasaran Dasar Pendekatan Manajerial Global. Jakarta : Salemba Empat.

[4] Kasmir. 2008. Manejemen Perbankan. Jakarta Rajagrafindo Persada.

[5] Lembaga Certif BPR. 2012. Materi Pemasaran Cerif Direksi BPR. Modul ke 6 .

[6] Liricolin Arsyad. 2011. Lembaga Keuangan Mikro Instuisi, Kinerja, dan Sustanabilitas. Yogyakarta : Andi.
[7] Lucas S. Muliawan. 2010. Wow ... Aha ... In Service. Meteri Pendidikan PT. BPR X. Modul ke 3.

[9] Malayu S.P, Hasibuan. 2005. Manajemen Dasar, Pengertian, [10] Philip Kotler, 2010. Manajemen Pemasaran : Analisis, Rerencanaan, Implementasi, dan Pengendalian. Jakarta : Salemba Empat.

[10] Philip Kotler, 2008. Manajemen Pemasaran Edisi Milenium 1. Jakarta : Indeks.

[11] Siregar, Syafaruddin. 2008. Statistik Terapan Untuk Penelitian. Jakarta: Grasindo.

[12] Stanton ,William J. 2010. Prinsip Pemasaran. Jakarta :Erlangga.

[13] The Official MIM Academy Coursebook. 2009. MarkPlus Basics. Jakarta : Esensi. 